\title{
Nonsyndromic Deafness - Molecular Update
}

\author{
Piatto V.B. ${ }^{*}, 1$, Secches L.V. ${ }^{1}$, Arroyo M.A.S. ${ }^{1}$, Lopes A.C.P. ${ }^{2}$ and Maniglia J.V. ${ }^{1}$ \\ ${ }^{1}$ Department of Otorhinolaryngology, Medical School of São José do Rio Preto (FAMERP), São Paulo, Brazil \\ ${ }^{2}$ Department of Morphology, Medical School of São José do Rio Preto (FAMERP), São Paulo, Brazil
}

\begin{abstract}
In most cases, hearing loss is a disorder caused by both genetic and environmental factors. The molecular description of deafness has experienced remarkable progress in the last decade, and it is emerging from the use of contemporary methods of cell and molecular biology. Currently, through the application of clinical and molecular genetics it is possible to identify genes associated with inherited, nonsyndromic deafness, and balance dysfunctions of the human cochlea. This brief review provides insights into nonsyndromic hearing loss, since the identification of the molecular basis for the inner ear function provides the basis for developing rational new approaches to diagnosis, management and treatment of auditory and vestibular disorders.
\end{abstract}

Keywords: Nonsyndromic, hearing loss, sensorineural, molecular genetics, gene.

\section{INTRODUCTION}

Approximately half the cases of prelingual hearing loss are caused by genetic factors. Identification of deafness of genetic origin is a crucial first step to understand the function of genes in the auditory system. About $60 \%$ of the cases have hereditary etiology, $30 \%$ of the cases are acquired and, $10 \%$ are idiopathic. Nonsyndromic forms are responsible for $70 \%$ of the cases of hereditary etiology and syndromic cases represent $30 \%$ of them. Among the forms of inheritance, autosomal recessive is the most frequent one (75\%-85\%), followed by dominant inheritance (12\%-13\%) and X-linked or mitochondrial, with $2 \%-3 \%$ of the cases of nonsyndromic hearing loss [1].

The aim of the present review is to assess the most recent insights into described mutant genes that cause varied forms of nonsyndromic hearing loss: autosomal recessive, dominant, X-linked and mitochondrial. Selected articles are from OMIM $^{\circledR}$ (Online Mendelian Inheritance in Man) [2] databases using MedLine, and the search mechanism used key words such as "nonsyndromic", "hearing loss", "sensorineural", "molecular genetics", and "gene". Selected articles were those that provided the most recent information about the genes involved and their respective proteins, their sites of expression in the cochlea and audiological clinical aspects. The symbols which used for the genes were approved by the HUGO Gene Nomenclature Committe (HGNC 2008) [3]. The selected references are in agreement with description of the genes from the Hereditary Hearing Loss Homepage [4] and OMIM [2] databases.

*Address correspondence to this author at the Rua Santina Figliagi Ceccato, 450 Ap-23A, Vila Itália, São José do Rio Preto, São Paulo, Brazil. Zip Code: 15035-180; Tel: +55-17-3201-5747; E-mail: vabp@bol.com.br, vabp@ig.com.br

\section{NOMENCLATURE OF NONSYNDROMIC HEARING LOSS}

Different chromosome loci of nonsyndromic forms of genetic deafness are named under the acronym DFN (from the word deafness) followed by the letters A or B, meaning autosomal dominant inheritance (DFNA) and recessive inheritance (DFNB), respectively. When using DFN isolated, it is X-linked deafness [5].

\section{HEARING PHYSIOLOGY}

The inner ear is a complex structure. A molecular description of its architecture is emerging from the use of contemporary methods of cell and molecular biology. With the application of clinical and molecular genetics, is now possible to identify genes associated with inherited, nonsyndromic deafness and balance dysfunction in the human cochlea. Therefore, to understand the consequences of gene mutations that regulate the hearing process one brief revision is necessary on the normal cochlear physiology. After the sound stimulus, the mechanical energy is converted into an electrical signal (mechanical-electrical transduction) in the outer hair cells of the cochlea. On the apical surface of these outer hair cells, there are specialized stereocilia which deflects in response to sound, which is secondary to the oval window stapes movement, moving the fluid that surrounds these hair cells. The deflection of stereocilia opens the transduction channels in them, allowing inflow of potassium from the endolymph to inner and outer hair cells of the cochlea causing depolarization of cell membrane and activating channels on the basolateral surface of the membrane, which are sensitive to voltage modifications. The subsequent influx of calcium causes release of neurotransmitters from the synaptic vesicles on to the primary afferent nerve ending synapses. Thus, after a sound stimulus, the inner and outer ear hair cells are hyperpolarized with high concentration of 
extracellular potassium. In order to make possible the next excitation, the potassium has to be removed. This movement of potassium ions from the ear hair cells to the cochlear supporting cells, going back to the endolymph, is made by intercellular specialized communications, the so-called gap junctions that exist among supporting cells, fibrocytes of the spiral ligament and the spiral limbus [6,7].

\section{MOLECULAR GENETIC OF NONSYNDROMIC HEARING LOSS}

\section{-Genetically Encoded Proteins with Expression in Cochlear Hair Cells (Table 1)}

\section{Unconventional Myosins}

Myosins are actin-dependent motor proteins with ATPase activity and are categorized into conventional myosins (class II) and unconventional myosins (classes I and III through $\mathrm{XV}$ ) based on their variable C-terminal cargo-binding domains. They are smaller than muscle myosin and for this reason they are called mini-myosins. Unconventional myosins act in intracellular movements. Their highly divergent tails are presumed to bind to membranous compartments, which are moved relative to actin filaments. In the inner ear, the actin filaments maintain the rigidity of stereocilia during the dynamic movements of the bundle $[8,9]$. The different types of unconventional myosins related to the auditory system are the following:

\section{a) Myosin IA}

The unconventional myosin protein IA is encoded by the MYO1A gene, located on 12q13-q15. Mutations is this gene cause DFNA48, characterized by sensorineural bilateral hearing loss of variable degree, usually ranging from moderate to severe but never profound hearing loss. The hearing loss appeared to be caused by a completely penetrant mutation with a variable age of onset: age 30 to 35 years for the first symptoms, and age 20 to 25 years for the first audiometric abnormalities [10].

Table 1. Molecular Genetics of Genes Causing Hearing Loss with Expression in Cochlear Hair Cells

\begin{tabular}{|c|c|c|c|c|c|}
\hline $\begin{array}{c}\text { Gene } \\
\text { Symbol }\end{array}$ & $\begin{array}{l}\text { Chromosomal } \\
\text { Locus }\end{array}$ & Protein & Function & Locus Name & Clinical Features/Age Onset \\
\hline MYOIA & $12 q 13-q 15$ & myosin protein IA & \multirow{7}{*}{$\begin{array}{l}\text { unconventional myosins act in } \\
\text { intracellular movements }\end{array}$} & DFNA48 & $\begin{array}{c}\text { hearing loss of variable degree } / 30 \\
\text { to } 35 \text { years }\end{array}$ \\
\hline MYO3A & $10 \mathrm{p} 11.1$ & myosin protein IIIA & & DFNB30 & progressive deafness $/ 2^{\text {nd }}$ decade \\
\hline MYO6 & $6 \mathrm{q} 13$ & myosin protein VI & & $\begin{array}{l}\text { DFNA22 and } \\
\text { DFNB37 }\end{array}$ & $\begin{array}{c}\text { progressive postlingual deafness/ } \\
\text { childhood }\end{array}$ \\
\hline MYO7A & $11 \mathrm{q} .13 .5$ & myosin protein VII & & $\begin{array}{l}\text { DFNB2 and } \\
\text { DFNA11 }\end{array}$ & $\begin{array}{c}\text { moderate deafness } / 20 \text { and } 60 \\
\text { years }\end{array}$ \\
\hline МYH9 & $22 \mathrm{q} 12.2-\mathrm{q} 13.3$ & myosin protein IX & & DFNA17 & $\begin{array}{l}\text { moderate-severe deafness } / 1^{\text {st }} \\
\text { decade }\end{array}$ \\
\hline MYH14 & $19 \mathrm{q} 13$ & myosin protein XIV & & DFNA4 & progressive deafness $/ 2^{\text {nd }}$ decade \\
\hline MYO15 & $17 \mathrm{p} 11.2$ & myosin protein $\mathrm{XV}$ & & & profound congenital deafness \\
\hline TMIE & 3 p14-p21 & $\begin{array}{l}\text { transmembrane } \\
\text { inner ear }\end{array}$ & $\begin{array}{l}\text { involved in protein and/or vesicle } \\
\text { trafficking }\end{array}$ & DFNB6 & $\begin{array}{l}\text { severe-to-profound prelingual } \\
\text { deafness }\end{array}$ \\
\hline$T M C 1$ & $9 q 13-q 21$ & $\begin{array}{l}\text { transmembrane } \\
\text { cochlear } 1\end{array}$ & specific function is unknown & $\begin{array}{l}\text { DFNB7/ } \\
\text { DFNB11 and } \\
\text { DFNA36 }\end{array}$ & $\begin{array}{c}\text { profound prelingual deafness; } \\
\text { progressive postlingual deafness } / 5 \\
\text { a } 10 \text { years }\end{array}$ \\
\hline OTOF & $2 \mathrm{p} 22-\mathrm{p} 23$ & otoferlin & $\begin{array}{l}\text { involved in vesicle membrane } \\
\text { fusion }\end{array}$ & DFNB9 & profound prelingual deafness \\
\hline $\mathrm{CDH} 23$ & $10 \mathrm{q} 21-\mathrm{q} 22$ & cadherin 23 & $\begin{array}{l}\text { involved in stereocilia organization } \\
\text { and hair bundle formation }\end{array}$ & DFNB12 & progressive prelingual deafness \\
\hline STRC & $15 q 21-q 22$ & stereocilin & associated with the stereocilia & DFNB16 & $\begin{array}{c}\text { non-progressive } \\
\text { deafness/childhood }\end{array}$ \\
\hline USHIC & $11 \mathrm{p} 14-15.1$ & harmonin & $\begin{array}{l}\text { part of a transmembrane complex } \\
\text { that connects stereocilia into a } \\
\text { bundle }\end{array}$ & DFNB18 & severe prelingual deafness \\
\hline PCDH15 & $10 \mathrm{p} 11.2-\mathrm{q} 21$ & protocadherin-15 & $\begin{array}{l}\text { morphogenesis and cohesion of } \\
\text { stereocilia bundles }\end{array}$ & DFNB23 & prelingual deafness \\
\hline$R D X$ & $11 \mathrm{q} 23$ & radixin & $\begin{array}{l}\text { linking actin to the plasma } \\
\text { membrane }\end{array}$ & DFNB24 & profound prelingual deafness \\
\hline TRIOBP & $22 \mathrm{q} 13$ & $\begin{array}{l}\text { trio- and f-actin- } \\
\text { binding protein }\end{array}$ & $\begin{array}{l}\text { controlling actin cytoskeleton } \\
\text { organization, cell motility and cell } \\
\text { growth }\end{array}$ & DFNB28 & profound prelingual deafness \\
\hline
\end{tabular}


(Table 1) Contd....

\begin{tabular}{|c|c|c|c|c|c|}
\hline $\begin{array}{c}\text { Gene } \\
\text { Symbol }\end{array}$ & $\begin{array}{l}\text { Chromosomal } \\
\text { Locus }\end{array}$ & Protein & Function & Locus Name & Clinical Features/Age Onset \\
\hline$W H R N$ & $9 q 32-q 34$ & whirlin & $\begin{array}{l}\text { coordinate polymerization of actin } \\
\text { for the growth of the membrane in } \\
\text { stereocilia }\end{array}$ & DFNB31 & profound prelingual deafness \\
\hline$S L C 26 A 5$ & $7 \mathrm{q} 22.1$ & prestin & essential for the auditory function & --- & moderate-to-severe deafness \\
\hline LHFPL5 & $6 \mathrm{p} 21.3$ & $\begin{array}{l}\text { lipoma } \mathrm{h} \text { fusion } \\
\text { partner protein }\end{array}$ & ear hair bundle morphogenesis & DFNB66/67 & profound congenital deafness \\
\hline $\begin{array}{l}D I A P H 1 \\
\text { or } H D I A\end{array}$ & $5 q 31$ & diaphanous & cell polarization and cytokinesis & DFNA1 & Progressive postlingual deafness \\
\hline$K C N Q 4$ & $1 \mathrm{p} 34$ & potassium channels & promote the outflow of potassium & DFNA2 & $\begin{array}{c}\text { progressive deafness/teens or } 20 \\
\text { years }\end{array}$ \\
\hline WFS1 & $4 \mathrm{p} 16.3$ & wolframin & $\begin{array}{l}\text { regulation of cellular } \mathrm{Ca}^{+2} \\
\text { homeostasis }\end{array}$ & $\begin{array}{c}\text { DFNA6 } \\
\text { (DFNA14/38) }\end{array}$ & $\begin{array}{l}\text { low frequency deafness } / 2^{\text {nd }} \\
\text { decade }\end{array}$ \\
\hline$P O U 4 F 3$ & $5 q 31$ & $\begin{array}{l}\text { transcription factor } \\
\text { POU4F3 }\end{array}$ & $\begin{array}{l}\text { maturation and survival of the } \\
\text { supporting cell layers }\end{array}$ & DFNA15 & $\begin{array}{c}\text { progressive deafness/18 and } 30 \\
\text { years }\end{array}$ \\
\hline$A C T G 1$ & $17 q 25$ & actin-gamma 1 & mediators of internal cell motility & DFNA20/26 & $\begin{array}{c}\text { progressive deafness } / 1^{\text {st }} \text { and } 2^{\text {nd }} \\
\text { decades }\end{array}$ \\
\hline$T F C P 2 L 3$ & $8 \mathrm{q} 22$ & $\begin{array}{l}\text { transcription factor } \\
\text { CP2-like } 3\end{array}$ & transcription factor & DFNA28 & progressive deafness/variable \\
\hline
\end{tabular}

\section{b) Myosin IIIA}

This unconventional protein is encoded by the $M Y O 3 \mathrm{~A}$ gene, located on 10p11.1. Expression of this gene is highly restricted, with the strongest expression in retina and cochlea (concentrated in inner and outer ear hair cells). This protein plays an important role in human hearing. Three different recessive mutations, with loss of function in the protein have been shown to cause bilateral progressive hearing loss (DFNB30), which affects primarily high frequencies, starting in the second decade, and at the age of 50, it reaches severe level in high and mid frequencies and moderate level in low frequencies [11].

\section{c) Mvosin VI}

It is an actin-based molecular motor involved in intracellular vesicle and organelle transport. The myosin protein VI is encoded by the MYO6 gene (6q13), and is concentrated in the cuticular plate in inner and outer ear hair cells. Mutations is this gene cause DFNA22 and DFNB37, characterized by progressive, and postlingual hearing loss with onset during childhood ( 8 to 10 years old to start symptoms, 6 to 8 years old for onset of audiometric alterations), and by the age of 50 approximately, affected individuals have profound sensorineural deafness $[12,13]$.

\section{d) Myosin VIIA}

It is expressed in inner and outer ear hair cells and in a variety of ciliated epithelial cells, including retinal retinal photoreceptors. In the cochlea, the protein localizes along the stereocilia, the inner and outer hair cells, and supporting cells, as well as in the synaptic terminals. The myosin VIIA is encoded by the MYO7A gene, located on 11q.13.5. Mutations in this gene cause structural defects of protein and consequent alterations in the auditory function, responsible for two nonsyndromic forms of hearing loss, one with profound recessive autosomal inheritance - DFNB2, comprising different grades of vestibular dysfunction, and another one that is autosomal dominant - DFNA11, which is characterized by bilateral sensorineural hearing loss without vertigo or associated symptoms. There are symmetric gently sloping or flat audiograms with hearing loss at all frequencies. Most affected individuals between ages 20 and 60 have moderate hearing loss. When the mutations cause also retina cell abnormalities, the phenotypic sign is characterized as Usher syndrome. The chromosomal locus for one of the genetic types of Usher syndrome - USH1B was also mapped to the same region of chromosome 11 , responsible for $75 \%$ of the cases of USH Type 1. Studies of mutation of the MYO7A gene causing DFNB2, DFNA11 and USH1B were the first to show that one gene could cause both non-syndromic and syndromic hearing loss respectively [14-16].

\section{e) Myosin IXA}

The conventional myosin protein IX is encoded by the MYH9 gene, located on 22q12.2-q13.3. The membranous cochlea (especially, inner and outer ear hair cells, and spiral limbus, spiral ligament, and spiral ganglion) and saccule are affected, but the osseous labyrinth, the membranous utricle, and the semicircular canals are normal. The affected members have nonsyndromic hearing loss with an autosomal dominant mode of transmission (DFNA17). The hearing loss begins at the age of 10 and involves only the high frequencies; by the third decade of life, affected family members have moderate to severe deafness [17].

\section{f) Myosin XIV}

The myosin XIV is a member of the nonmuscle myosin II family of ATP-dependent molecular motors, which 
interacts with cytoskeletal actin and regulates cytokinesis, cell motility, and cell polarity. The MYH14 gene - myosin heavy chain 14 , located on $19 \mathrm{q} 13$, encodes a member of the myosin superfamily, the myosin XIV, which is expressed as in ear hair cells as cochlear supporting cells up to the lateral wall cells, including Reissner's membrane. Mutations in this gene result in one form of hearing impairment (DFNA4), which is characterized by a fluctuating, inexorably progressive hearing loss, with onset in the second decade and leads from severe to profound impairment at the age of 40 [18].

\section{g) $\operatorname{Myosin} X V$}

The myosin XV is encoded by the MYO15 gene, located on $17 \mathrm{p} 11.2$. This myosin differs from others having a long $\mathrm{N}$-terminal extension preceding the conserved motor domain. This protein is necessary for actin organization in the inner and outer hair cells of the cochlea, especially to the cuticular plate. Mutations in this gene have been associated with profound and congenital deafness due to an autosomal recessive mutation at a locus designated DFNB3 [19].

\section{Transmembrane Inner Ear - TMIE}

This protein, encoded by the TMIE gene (3p14-p21), may play some role in a cellular membrane location. It may reside within an internal membrane compartment and function in pathways such as those involved in protein and/or vesicle trafficking. Deafness (DFNB6) is caused by mutation in the transmembrane inner ear-expressed gene, characterized by severe-to-profound prelingual deafness [20].

\section{Transmembrane Cochlear 1 - TMCI}

The $T M C 1$ gene, located on $9 \mathrm{q} 13-\mathrm{q} 21$, is considered a member of a gene family predicted to encode transmembrane proteins, but its specific function is unknown; however, it is known to be required for normal function of cochlear hair cells. The protein Tmc1 is expressed in hair cells of the postnatal cochlea and vestibular end organs. Mutations in this gene have been associated with profound prelingual deafness (DFNB7/DFNB11) and progressive postlingual hearing loss (DFNA36), characterized by bilateral, symmetric hearing loss that begins from 5 to 10 years of age and rapidly progresses to profound deafness within 10 to 15 years. Affected individuals have no evidence of vestibular deficits in their developmental, and medical histories or upon physical examination [21].

\section{Otoferlin}

The otoferlin protein, which is expressed in inner ear hair cells, is involved in vesicle membrane fusion, and is encoded by the OTOF gene, located on 2p22-p23. Mutation in this gene causes DFNB9, characterized by prelingual profound hearing loss involving all frequencies, starting at birth or before the age of 2 years. None of the patients have balance problems. The audiometry shows no response at $100 \mathrm{~dB}$ at frequencies above $1,000 \mathrm{~Hz}$ in all affected subjects [22]. There is a specific type of deafness, caused by OTOF gene, termed 'nonsyndromic recessive auditory neuropathy' (NSRAN). Affected patients have hearing loss based on pure-tone audiometry and auditory brainstem response test results, which measure the overall auditory pathway, but have a normal otoacoustic emissions (OAE) test, which detects responses of the outer hair cells to environmental sound. Subjects with NSRAN can have varying degrees of hearing loss with poor speech reception out of proportion to the degree of hearing loss. Most subjects with NSRAN are not helped by hearing aids, but may be helped by cochlear implants [23].

\section{Cadherin 23}

The $C D H 23$ gene is a member of the cadherin superfamily encoding calcium dependent cell-cell adhesion glycoproteins. Expressed in the neurosensory epithelium, this protein is thought to be involved in stereocilia organization and hair bundle formation. This gene is located in a region containing the human deafness loci DFNB12 (10q21-q22) and USH1D (USH1D - 10q). The cadherin 23 protein is expressed in inner and outer cochlear hair cells, promoting strong adhesion between them, and in Reissner's membrane. Mutations of the $C D H 23$ gene cause DFNB12, characterized by moderate to profound high-frequency progressive sensorineural prelingual hearing loss. The average hearing loss is $84.0 \mathrm{~dB}$. Vestibular function is normal [24].

\section{Stereocilin}

The stereocilin protein is expressed in the sensory ear hair cells and is associated with the stereocilia, is encoded by the STRC gene, located on 15q21-q22. Mutations in this gene cause DFNB16 characterized by bilateral, non-progressive, sensorineural hearing loss, with onset in early childhood. The hearing impairment involves all frequencies, is moderate in the range of $125-1000 \mathrm{~Hz}$, but is severe in the higher frequencies. Vestibular function is normal, and there are no symptoms of tinnitus [25].

\section{Harmonin}

The USH1C gene, located on 11p14-15.1 encodes a protein, designate Harmonin, that contains the PDZ domain (Post synaptic density protein, Drosophila disc large tumor supressor, Zonnula occludens-1 protein). In the cochlea, harmonin is restricted to inner and outer hair cells, in which it is present in the cellular body and stereocilia and this protein is also expressed in the ribbon synapses. Defects in USH1C gene are the cause of DFNB18, characterized by prelingual and severe deafness. The functional characterization of the expression of harmonin protein provides the understanding of the pathogenesis of DFNB18 and USH1C syndrome $[26,27]$.

\section{Protocadherin 15}

The PCDH15 gene is also a member of the cadherin superfamily. The protocadherin- 15 protein, which consists of a signal peptide, 11 extracellular calcium-binding domains, a transmembrane domain and a unique cytoplasmic domain, is encoded by the PCDH15 gene, located on 10p11.2-q21. In the cochlea, protocadherin-15 is restricted to the cuticular plate of the inner and outer hair cells and external supporting 
cells, beyond the spiral ganglion. Mutations in this gene have been associated with non-syndromic prelingual hearing loss (DFNB23), which is consistent with its location at the Usher syndrome type $1 \mathrm{~F}$ (USH1F), critical region on chromosome 10 [28].

\section{Radixin}

Radixin is a cytoskeletal protein that may be important in linking actin to the plasma membrane. It is highly similar in sequence to both ezrin and moesin. The radixin, which is localizated along the length of cochlear hair cell stereocilia and in hair cells of the crista ampullaris at postnatal day 30, is encoded by the $R D X$ gene, located on $11 \mathrm{q} 23$. The deafness (DFNB24) is characterized by prelingual onset and is bilateral and profound, and there is no vestibular dysfunction [29].

\section{Trio- and F-Actin-Binding Protein - TRIOBP}

The TRIOBP gene, located on 22q13, encodes a trio- and f-actin-binding protein that interacts with trio, which is involved with neural tissue development and controlling actin cytoskeleton organization, cell motility and cell growth. This trio-binding protein also associates with F-actin and stabilizes F-actin structures. This protein is expressed in sensory cells of the inner ear and colocalizes with F-actin along the length of the stereocilia. Mutations in this gene have been associated with a form of deafness (DFNB28), characterized by prelingual bilateral symmetrical and profound sensorineural hearing loss [30, 31].

\section{Whirlin}

This protein, encoded by the WHRN gene (9q32-q34), acts as an organizer of submembranous molecular complexes that control and coordinate polymerization of actin for the growth of the membrane in stereocilia of the inner and outer ear hair cells. The whirlin protein is similar to harmonin protein because it shares $95 \%$ of its three PDZ domains. Mutation in this gene is responsible for prelingual profound deafness (DFNB31) [32], and WHRN mutations may also cause USH2D syndrome [33].

\section{Espin}

The espin protein that is present in inner and outer ear hair cell stereocilia, is encoded by the ESPN gene, located on 1p36.1. A recessive mutation in this gene causes prelingual profound hearing loss (DFNB36), by ear hair cell degeneration, and the affected individuals show an independent ambulation delayed beyond 1.5 years of age by vestibular dysfunction [34].

\section{Prestin}

The SLC26A5 gene, located on 7q22.1, is a member of the solute carrier (SLC) transporter family 26 (SLC26A). It encodes prestin, a motor membrane protein that is specifically expressed in outer hair cells of the cochlea and is essential for the auditory function. Intracellular anions are thought to act as extrinsic voltage sensors, which bind to this protein and trigger the conformational changes required for rapid length changes in outer ear hair cells. Mutations in this gene have been associated with nonsyndromic hearing loss, characterized by moderate-to-severe hearing loss and deterioration of frequency selectivity [35].

\section{Lipoma H Fusion Partner Like Protein 5 - LHFPL5}

The LHFPL5 gene, located on 6p21.3, is a member of the lipoma HMGIC fusion partner (LHFP) gene family, which is a subset of the superfamily of tetraspan transmembrane protein encoding genes. This gene encodes lipoma $\mathrm{h}$ fusion partner protein, which is proposed to function in ear hair bundle morphogenesis. Mutations in the LHFPL5 gene result in profound congenital deafness (DFNB66/67), and audiometric tests show loss of hearing greater than $70 \mathrm{~dB}$ for all frequencies tested [36-38].

\section{Diaphanus}

This protein belongs to a family of proteins related to formins, involved in cell polarization and cytokinesis. The diaphanous protein is encoded by the DIAPHI or HDIAI gene (5q31), that is homolog of the Drosophila diaphanous gene. In the cochlea, the protein is found in inner and outer hair cells and external supporting cells. Gene mutations affect the cytoskeleton of actin in outer ear hair cells and cause DFNA1, characterized by progressive low-frequency and postlingual hearing loss (with onset at about the age of 10, after language and speaking were learned). At the age of 40 , approximately, hearing loss reaches severe level in all frequencies [39].

\section{Potassium Channel, Voltage-Gated, KQT-Like Subfamily, Member 4 - KCNQ4}

The protein subunit of family KCNQ of potassium channels, named KCNQ4 protein, is encoded by the KCNQ4 gene, located on $1 \mathrm{p} 34$. In the cochlea, KCNQ4 channels are expressed not only in the outer hair cells, but also in the inner hair cells, and in the spiral ganglion, whose main function is to promote the outflow of potassium from these cells to the supporting cells [40]. Mutations in this gene are the cause of DFNA2, an autosomal dominant form of progressive hearing loss. The hearing loss first affect the high frequencies during the teens or $20 \mathrm{~s}$, becoming profound within 10 years $[41,42]$.

\section{Wolframin}

This transmembrane protein participates in the regulation of cellular $\mathrm{Ca}^{+2}$ homeostasis, at least partialy, by modulating the filling state of the endoplasmic reticulum $\mathrm{Ca}^{+2}$ store. It is encoded by the WFS1 gene (4p16.3), which is expressed in inner and outer ear hair cells and external supporting cells, beyond the spiral ligament, interdental cells, Reissner's membrane, and spiral ganglion. Mutations in this gene are associated with an autosomal recessive syndrome (Wolfram syndrome), and it can also cause DFNA6, also known as DFNA14 or DFNA38. Low frequency sensorineural hearing loss is an unusual type of hearing loss in which frequencies of $2000 \mathrm{~Hz}$ and below are predominantly affected. Many patients have tinnitus, but there are otherwise no associated features such as vertigo. Because high-frequency hearing is generally preserved, patients retain excellent understanding of speech, although presbycusis or noise exposure may cause 
high-frequency loss later in life. DFNA6 worsens over time without progressing to profound deafness [43-45].

\section{Pou Domain, Class 4, Transcription Factor 3 - POU 4F3}

The transcription factor POU4F3 protein is encoded by the POU4F3 gene, located on 5q31. In inner and outer hair cells in the cochlea, the POU4F3 gene seems to express during their migration from the supporting cell layers to the hair cell layer of the lumen, and also in their maturation and survival. A mutation found in $P O U 4 F 3$ gene causes DFNA15, a progressive deafness, which starts between 18 and 30 years, and which reaches from moderate to severe level at the age of 50, approximately [46].

\section{Actin-Gamma 1 - ACTG1}

Actins are a family of highly conserved cytoskeletal proteins that are involved in various types of cell motility, and maintenance of the cytoskeleton. The alpha actins are found in muscle tissues and are a major constituent of the contractile apparatus. The beta and gamma actins co-exist in most cell types as components of the cytoskeleton, and as mediators of internal cell motility. Actin-gamma 1, encoded by the $A C T G 1$ gene (17q25), is a cytoplasmic actin found in nonmuscle cells, but much of the specialized ultrastructural organization of the cells in the cochlea is based on the actin cytoskeleton, especially inner and outer ear hair celss. Mutation in this gene is responsible for DFNA20/26, characterized by the onset in the first or second decade of life, high frequencies and progressive hearing loss involving all frequencies. Audiograms show a sloping configuration with age, resulting in profound hearing loss. The rate of progression is variable; a hearing aid wil be needed by the age of $20[47,48]$.

\section{Transcription Factor CP2-Like 3 - TFCP2}

This protein, encoded by the $\boldsymbol{T F C P 2 L 3}$ gene (8q22), is a member of a family of transcription factor genes whose archetype is TFCP2, a mammalian ortholog of the Drosophila gene 'grainyhead' (grh). In the cochlea, this protein is expressed in inner and outer hair cells, beyond external supporting cells, stria vascularis, Reissner's membrane, inner sulcus cells and interdental cells. Mutations in this gene have been associated with DFNA28, characterized by a mild to moderate deafness across most frequencies that progress to severe loss in the higher frequencies by the fifth decade, with variable age of onset [49].

\section{- Genetically Encoded Proteins with Expression in Cochlear Non-Sensorial Cells (Table 2)}

\section{Connexin}

Connexin protein is the structural component of intercellular gap junctions, which is responsible for the flow of potassium from the inner and outer ear hair cells, to the supporting cells, then the fibrocytes of the spiral ligament and spiral limbus, and back to the endolymph. One gap junction consists of a cluster of closely packed pairs of transmembrane channels, the connexons, through which materials of low molecular weight diffuse from one cell to a neighboring cell. A connexon is composed of a hexamer of connexins. The connexins are designated by their molecular mass. Another system of nomenclature divides gap junction proteins into 2 categories, alpha and beta, according to sequence similarities at the nucleotide and amino acid levels. For example, CX43 is designated alpha-1 gap junction protein, whereas CX32 and CX26 are called beta- 1 and beta2 gap junction proteins, respectively. This nomenclature emphasizes that CX32 and CX26 are more homologous to each other than either of them is to CX43 [50].

The different types of connexins related to the auditory system are the following:

\section{a) Connexin 26}

The connexin protein 26 is encoded by the $C X 26$ or GJB2 gene, located on 13q11-12. Mutations in this gene are responsible for both forms of hearing loss - DFNA3 and DFNB1, characterized by prelingual, non-progressive, and profound deafness [51, 52].

\section{b) Connexin 30}

The connexin protein 30 is encoded by the $C X 30$ or GJB6 gene, located at de same CX26 gene locus-13q11-12. Mutations in this gene are responsible for both forms of hearing loss - DFNA3 and DFNB1 (both forms also are caused by $C X 26$ gene). If no mutation is found in $C X 26$ gene or in heterozygote patients for $35 \mathrm{delG}$ mutation, mutations of $C X 30$ gene, by its close relation (about $76 \%$ identical amino acids) and proximity of its chromosomic locus to CX26 gene, they may be considered responsible for hearing loss, named similarly to $C X 26$ gene. This fact is explained, in addition to proximity, by the fact that $C X 26$ and $C X 30$ genes may form heterotopic channels of connexons, and they have the same cellular distribution in the cochlea. Therefore, pathophysiological hypotheses concerning hearing loss associated with both genes are similar $[53,54]$.

\section{c) Connexin 31}

The connexin protein 31 is present in both spiral limbus and spiral ligament. The locus of $C X 31$ or GJB3 gene (1p34) is the same for $K C N Q 4$ gene, which is expressed only in inner and outer ear hair cells, and if mutant it causes DFNA2. Owing to that, mutations in the $C X 31$ gene also cause dominant hearing loss, but although with expression in different site of $K C N Q 4$ gene, both received the same name DFNA2 [55].

\section{DFNA5}

This protein is encoded by the DFNA5 gene, located on 7p15. It is expressed in fetal cochlea, however, its function is not known. Mutations in DFNA5 gene are the cause of DFNA5, characterized by progressive hearing loss starting in the high frequencies [56].

\section{Pendrin/Solute Carrier Family 26, Member 4 -SLC26A4}

The pendrin is encoded by the $S L C 26 A 4$ gene, located on 7q31. In the mature cochlea, the pendrin protein is expressed in spiral prominence, external sulcus cells, Claudius cells, Deiters' cells, and spiral ganglion Mutations in this gene are 
Table 2. Molecular Genetics of Genes Causing Hearing Loss with Expression in Cochlear Non-Sensorial Cells

\begin{tabular}{|c|c|c|c|c|c|}
\hline $\begin{array}{c}\text { Gene } \\
\text { Symbol }\end{array}$ & $\begin{array}{l}\text { Chromosomal } \\
\text { Locus }\end{array}$ & Protein & Function & Locus Name & Clinical Features/Age Onset \\
\hline $\begin{array}{l}C X 26 \text { or } \\
\text { GJB2 }\end{array}$ & $13 q 11-12$ & connexin 26 & \multirow{3}{*}{$\begin{array}{l}\text { responsible for the flow of } \\
\text { potassium }\end{array}$} & $\begin{array}{l}\text { DFNA3 and } \\
\text { DFNB1 }\end{array}$ & $\begin{array}{c}\text { non-progressive prelingual } \\
\text { deafness }\end{array}$ \\
\hline $\begin{array}{l}C X 30 \text { or } \\
\text { GJB6 }\end{array}$ & $13 q 11-12$ & connexin 30 & & $\begin{array}{l}\text { DFNA3 and } \\
\text { DFNB1 }\end{array}$ & $\begin{array}{c}\text { non-progressive prelingual } \\
\text { deafness }\end{array}$ \\
\hline $\begin{array}{l}C X 31 \text { or } \\
\text { GJB3 }\end{array}$ & $1 \mathrm{p} 34$ & connexin 31 & & DFNA2 & $\begin{array}{l}\text { progressive deafness/ teens or } \\
20 \text { years }\end{array}$ \\
\hline$S L C 26 A 4$ & $7 \mathrm{q} 31$ & pendrin & anion transporter & DFNB4 & $\begin{array}{c}\text { progressive congenital } \\
\text { deafness }\end{array}$ \\
\hline TMPRSS3 & $21 \mathrm{q} 22$ & $\begin{array}{c}\text { transmembrane protease } \\
\text { serine } 3\end{array}$ & proteolytic activity & $\begin{array}{l}\text { DFNB10/ } \\
\text { DFNB8 }\end{array}$ & congenital deafness/childhood \\
\hline OTOA & $16 \mathrm{p} 12.2$ & otoancorin & $\begin{array}{l}\text { noncollageneous glycoprotein } \\
\text { unique to the inner ear }\end{array}$ & DFNB22 & $\begin{array}{c}\text { moderate-to-severe prelingual } \\
\text { deafness }\end{array}$ \\
\hline CLDN14 & $21 \mathrm{q} 22$ & claudin 14 & $\begin{array}{c}\text { component of tight junction } \\
\text { strands }\end{array}$ & DFNB29 & profound congenital deafness \\
\hline$M A R V E L D 2$ & $5 q 12.3-q 14.1$ & tricellulin & $\begin{array}{l}\text { component of tricellular tight } \\
\text { junctions }\end{array}$ & DFNB49 & profound congenital deafness \\
\hline PJVK & $2 \mathrm{q} 31.1-\mathrm{q} 31.3$ & pejvakin & $\begin{array}{l}\text { essential in the activity of auditory } \\
\text { pathway neurons }\end{array}$ & DFNB59 & profound prelingual deafness \\
\hline $\mathrm{COCH}$ & $14 q 12-q 13$ & cochlin & $\begin{array}{l}\text { integrate into the extracellular } \\
\text { matrix }\end{array}$ & DFNA9 & $\begin{array}{c}\text { progressive deafness/20 and } 30 \\
\text { years }\end{array}$ \\
\hline EYA4 & $6 q 22-23$ & eyes absent 4 & $\begin{array}{l}\text { continued function of the mature } \\
\text { organ of Corti }\end{array}$ & DFNA10 & $\begin{array}{c}\text { progressive postlingual } \\
\text { deafness }\end{array}$ \\
\hline$C C D C 50$ & $3 q 28-29$ & $\begin{array}{l}\text { coiled-coil domain- } \\
\text { containing protein } 50\end{array}$ & $\begin{array}{l}\text { effector of epidermal growth } \\
\text { factor-mediated cell signaling }\end{array}$ & DFNA44 & progressive deafness $/ 1^{\text {st }}$ decade \\
\hline$C R Y M$ & $16 \mathrm{p} 13.11-\mathrm{p} 12.3$ & mu-crystallin & $\begin{array}{l}\text { possible involvement in the } \\
\text { potassium-ion recycling system }\end{array}$ & DFNA- & $\begin{array}{l}\text { progressive deafness } / 19 \\
\text { months }\end{array}$ \\
\hline POU3F4 & Xq21.1 & $\begin{array}{l}\text { pou domain, class } 3 \text {, } \\
\text { transcription factor } 4\end{array}$ & $\begin{array}{c}\text { a role in potassium ion } \\
\text { homeostasis has been postulated }\end{array}$ & DFN3 & $\begin{array}{l}\text { profound sensorineural } \\
\text { deafness }\end{array}$ \\
\hline
\end{tabular}

also associated with Pendred syndrome (7q21-34), the most common form of syndromic deafness. DFNB4 is characterized by progressive hearing loss and widening of vestibular aqueduct, without thyroid affection [57].

\section{Serine 3}

The transmembrane protease serine 3 protein, that belongs to the serine protease family, is encoded by the TMPRSS3 gene, located on 21q22. This gene was identified by its association with both congenital (DFNB10) and childhood onset deafness (DFNB8). It is expressed in fetal cochlea (supporting cells, scala vestibuli cells, and spiral ganglion) and many other tissues, and is thought to be involved or in the development and maintenance of the inner ear or in the contents of the perilymph and endolymph [58].

\section{Otoancorin}

All of the noncollageneous glycoproteins of the acellular gels of the inner ear that have been described in mammals, namely alpha-tectorin, beta-tectorin, and otogelin, are molecules unique to the inner ear. The otoancorin protein is encoded by the OTOA gene (16p12.2). Mutations in this gene have been associated with a moderate-to-severe prelingual deafness (DFNB22) [59].

\section{Claudin 14}

This protein, encoded by the CLDN14 gene (21q22), is member of the claudin family, is an integral membrane protein and a component of tight junction strands. In the cochlea, this gene is expressed in tight junctions of inner sulcus cells, inner pillar cells, Deiters cells, and in inner and outer hair cells. Mutations in this gene are the cause of a profound autosomal recessive form of nonsyndromic sensorineural deafness (DFNB29) [60].

\section{Marvel Domain-Containing Protein 2 - MARVELD2}

This protein, encoded by the MARVELD2 gene (5q12.3q14.1), also named tricellulin, is an integral membrane protein concentrated at the vertically oriented tight junctions strands of tricellular contacts. In the inner ear, tricellulin is 
concentrated at the tricellular tight junctions in cochlear and vestibular epithelia, including the structurally complex and extensive junctions between supporting and ear hair cells. Mutations in this gene are the cause of a congenital profound hearing loss (DFNB49) of all frequencies [61, 62].

\section{Pejvakin}

The pejvakin protein, which is essential in the activity of auditory pathway neurons, is encoded by the PJVK gene, located on 2q31.1-q31.3. Pejvakin is detected in the cell bodies of neurons of the afferent auditory pathway. Mutations in PJVK gene are the cause of deafness (DFNB59), characterized by prelingual profound deafness involving all frequencies, and with absent or severely abnormal auditory brainstem response but normal otoacoustic emissions (auditory neuropathy or auditory dyssynchrony) [63].

\section{Cochlin}

This protein, encoded by the $\mathrm{COCH}$ gene (14q12-q13), is detected in spindle-shaped cells located along nerve fibers between the auditory ganglion, and extracellular matrix, especially bone spiral lamina, spiral limbus and spiral ligament. These cells accompany neurites at the habenula perforata, the opening through which neurites extend to innervate ear hair cells. Mutations in this gene are responsible for DFNA9, which starts between the ages of 20 and 30 years, approximately. Initially, it is profound in high frequencies and shows variable progression to anacusis at the age 40-50. The spectrum of vestibular involvement varies from absence of symptoms to presence of vertigo and vestibular hypofunction. Histopathological analyses of temporal bone in patients with DFNA9 show deposits of mucopolysaccharides in the channels of the cochlear and vestibular nerves, which apparently, cause strangulation and degeneration of dendritic fibers [64].

\section{Eyes Absent 4 - EYA4}

The EYA4 gene, located on 6q22-23, encodes a member of the eyes absent (EYA) family of proteins. This protein may act as a transcriptional activator and may be important for continued function of the mature organ of Corti. Mutations in this gene are associated with postlingual (onset in 2nd to 5th decades) progressive deafness (DFNA10). Losses start in mid frequencies and eventually involve low and high frequencies. There are no morphological anomalies of the cochlea, unlike those that result from mutations in the EYAl gene, which causes BOR syndrome (Branchio-OtoRenal Syndrome [65].

\section{Coiled-Coil Domain-Containing Protein 50 - CCDC50}

This protein, encoded by the CCDC50 gene (3q28-29), is associated with microtubules of the cytoskeleton and mitotic apparatus, which encodes an effector of epidermal growth factor-mediated cell signaling. Mutations in CCDC50 gene are the cause of DFNA44. The hearing loss is initially moderate and affects mainly low to mid frequencies. Later, it progresses and involves all the frequencies and leads to a profound hearing loss by the 6th decade. The onset of the hearing loss occurs in the 1st decade of life (6-10 years of age). The DFNA44 hearing loss may result from a timedependent disorganization of the microtubule-based cytoskeleton in the pillar cells and stria vascularis of the adult auditory system [66].

\section{Crystallin, $M U$}

There is strong expression of mu-crystallin protein, encoded by the CRYM gene (16p13.11-p12.3), only in the inner ear tissues - fibrocytes of spiral limbus and spiral ligament. Autosomal dominant hearing impairment (DFNA) has been identified at age of 19 months. Auditory brainstem responses, conditioned orientation reflex audiometry, and pure-tone audiometry examinations show bilateral moderate sensorineural hearing loss (average 50-60 dB) affecting all frequencies by a downsloping audiogram pattern. Hearing loss progresses from moderate to severe $(70 \mathrm{~dB})$ bilaterally at the age of 13 with the carolic test showing normal vestibular function [67].

\section{Pou Domain, Class 3, Transcription Factor 4 - POU 3F4}

This protein, encoded by the POU3F4 gene (Xq21.1), is expressed in the fibrocytes of the spiral ligament and bone spiral lamina, and in Reissner's membrane in cochlea. Mutations in this gene cause DFN3 (DFNX2), the first nonsyndromic X-linked deafness that was identified. This mixed type of deafness is characterized by both conductive hearing loss resulting from stapes fixation and progressive sensorineural deafness, and that sometimes a profound sensorineural deafness masks the conductive element. Computerized tomography demonstrated abnormal dilatation of the internal acoustic canal, as well as an abnormally wide communication between the internal acoustic canal and the inner ear compartment. As a result, there is an increased perilymphatic pressure that is thought to underlie the observed 'gusher' during the opening of the stapes footplate. Therefore, the DFN3 should be characterized, not by mixed conductive and sensorineural deafness associated with perilymphatic gusher at stapes surgery, but by profound sensorineural deafness, which is the sine qua non of this disorder, with or without a conductive component associated with a unique developmental abnormality of the ear [68].

\section{- Genetically Encoded Proteins with Expression in Tectorial Membrane (Table 3)}

The tectorial membrane is an extracellular matrix of the inner ear that contacts the stereocilia bundles of specialized sensory hair cells. Sound induces movement of these hair cells relative to the tectorial membrane, deflects the stereocilia, and leads to fluctuations in hair-cell membrane potential, transducing sound into electrical signals [69].

\section{Collagen XI}

The collagen 12 protein, one of the two alpha chains of type XI collagen, a minor fibrillar collagen, which is one of the components of the tectorial membrane, is encoded by the COL11A2 gene, located on 6p21. Type XI collagen is a heterotrimer but the third alpha chain is a post-translationally modified alpha 1 type II chain. Mutations in this 
Table 3. Molecular Genetics of Genes Causing Hearing Loss with Expression in Tectorial Membrane

\begin{tabular}{|c|c|c|c|c|c|}
\hline $\begin{array}{l}\text { Gene } \\
\text { Symbol }\end{array}$ & $\begin{array}{l}\text { Chromosomal } \\
\text { Locus }\end{array}$ & Protein & Function & Locus Name & Clinical Features/Age Onset \\
\hline COL11A2 & $6 \mathrm{p} 21$ & $\begin{array}{c}\text { collagen } \\
12\end{array}$ & $\begin{array}{l}\text { one of the components of the } \\
\text { tectorial membrane }\end{array}$ & DFNA13 and DFNB53 & $\begin{array}{l}\text { progressive deafness } / 2^{\text {nd }} \text { to } 4^{\text {th }} \text { decades } \\
\text { profound prelingual deafness }\end{array}$ \\
\hline TECTA & $11 \mathrm{q} 22$ & $\begin{array}{l}\text { alpha- } \\
\text { tectorin }\end{array}$ & $\begin{array}{l}\text { non-collagenous component of } \\
\text { the tectorial membrane }\end{array}$ & $\begin{array}{l}\text { DFNA8/DFNA12 and } \\
\text { DFNB21 }\end{array}$ & non-progressive prelingual deafness \\
\hline
\end{tabular}

gene are associated with type III Stickler syndrome, otospondylomegaepiphyseal dysplasia (OSMED syndrome), Weissenbacher-Zweymuller syndrome, and DFNA13, which is characterized by progressive hearing loss beginning in the second to fourth decades, eventually making use of amplification mandatory [70,71], and DFNB53 which is characterized by prelingual, profound, nonprogressive, and nonsyndromic sensorineural hearing loss [72].

\section{Alpha-Tectorine}

The alpha-tectorin protein, one of the major non-collagenous components of the tectorial membrane, is encoded by the TECTA gene, located on 11q22. Mutations in the TECTA gene have been shown to be responsible for two forms of hearing impairment (DFNA8 and DFNA12) and a recessive form of deafness (DFNB21). The DFNA8 is characterized by moderate to severe, prelingual onset, and is relatively stable or non-progressive. Pure tone audiometry shows hearing loss between 60 and $80 \mathrm{~dB}$, with a maximum at $2,000 \mathrm{~Hz}$ (severe range 1,000 to $6,000 \mathrm{kHz}$ ), and a U-shaped curve. The DFNA12 is characterized by mid frequency ( 500 to $2,000 \mathrm{~Hz}$ ) hearing loss with prelingual onset. There is not progression with age. The DFNB21 is characterized by prelingual severe to profound sensorineural isolated form of deafness $[73,74]$.

\section{- Nonsyndromic Hearing Loss Caused by Mitochondrial Mutations}

Maternally inherited mitochondrial mutations give rise to nonsyndromic hearing impairment in some patients. However, for some mutations, patients have been found with additional symptoms accompanying the hearing impairment [75].

\section{Ribosomal RNA, Mitochondrial, 12S - MTRNR1}

The mitochondrial ribosome in the cochlea is the most likely target of aminoglycoside ototoxicity, since the 'natural target' of aminoglycosides is the evolutionarily related bacterial ribosome. In bacterial studies, regions of the small ribosomal RNA appear to be important in translational fidelity. Thus, the mitochondrial rRNA genes, and especially the $12 S$ rRNA gene (MTRNRI), were prime candidates for the site of the mtDNA mutations in maternally inherited aminoglycoside-induced deafness [76].

\section{Transfer RNA, Mitochondrial, Serine, 1- MTTS1}

To present, other described nonsyndromic mitochondrial mutations that cause hearing loss, followed or not by other symptoms, are located tRNASer (UCN) gene: a) palmoplantar keratoderma with progressive, postlingual, and involved high frequencies, b) mitochondrial encephalopathy with cytochrome c oxidase deficiency associated with sensorineural hearing loss, ataxia, myoclonic epilepsy, and mental retardation c) prelingual bilateral severe sensorineural deafness, and bilateral and permanent tinnitus with onset at age 20 years. There are no additional symptoms reported [77].

Recent studies suggested that mitochondrial mutation, such as the deletion mtDNAdel $4977 \mathrm{bp}$, may be responsible for familial cases of presbyacusis in some populations $[78,79]$.

\section{CONCLUDING REMARKS}

The understanding of the complexities of the architectural organization necessary for cochlear and vestibular function has advanced so rapidly that the inner ear is becoming a major model for post-genomic studies, the attempt to discover for actual coding of the human genome genes. The identification of the molecular basis of inner ear function is setting the basis for developing rational new approaches to early diagnosis, management and treatment (gene therapy, drug treatment) of auditory and vestibular disorders.

\section{CONFLICT OF INTEREST}

There are no financial bounds or agreements between the authors and companies that may be interested in the material addressed in this Article.

\section{ACKNOWLEDGEMENT}

We thank our friend and translator Cecília Meneguette Ferreira for her considerable aid.

\section{REFERENCES}

[1] Mustafa T, Arnos KS, Pandya A. Advances in hereditary deafness Lancet 2001; 358: 1082-90.

[2] OMIM. Online Mendelian Inheritance in Man [homepage on the Internet]. Baltimore, USA: John Hopkins University [cited on 2009 Jan 15]. Avaiable from: http://www.ncbi. nlm. nih.gov/omim

[3] HUGO Gene Nomenclature Committee (HGNC) [homepage on the Internet]. Cambridge, UK: National Human Genome Research Institute (NHGRI) and Wellcome Trust. [updated 2007 Febr 16; cited on 2009 Jan 15]. Available from: http://www. genenames.org 
[4] Van Camp G, Smith R (2008). Hereditary Hearing Loss Homepage [homepage on the Internet]. Antwerp, Be: University of Antwerp. [update 2008 May 28, cited on 2009 Jan 15]. Avaiable from: http://webh01.ua.ac.be/hhh/

[5] Van Camp G, Willems PJ, Smith RJH. Nonsyndromic hearing impairment: unparalleled heterogeneity. Am J Hum Genet 1997; 60: 758-64.

[6] Kikuchi T, Adams JC, Miyabe Y, So E, Kobayashi T. Potassium ion recycling pathway via gap junction systems in the mammalian cochlea and its interruption in hereditary nonsyndromic deafness. Med Electron Microsci 2000; 33: 51-6

[7] Willems PJ. Genetic causes of hearing loss. N Engl J Med 2000; 342:1101-9.

[8] Libby RT, Steel KP. The roles of unconventional myosins in hearing and deafness. Essays Biochem 2000; 35: 159-74.

[9] Sellers JR. Myosins: a diverse superfamily. Biochim Biophys Acta 2000; 1496: 3-22.

[10] Donaudy F, Ferrara A, Esposito L, et al. Multiple mutations of MYO1A, a cochlear-expressed gene, in sensorineural hearing loss. Am J Hum Genet 2003; 72: 1571-7.

[11] Walsh T, Walsh V, Vreugde S, et al. From flies' eyes to our ears: mutations in a human class III myosin cause progressive nonsyndromic hearing loss DFNB30. Proc Nat Acad Sci 2002; 99: 7518-23.

[12] Melchionda S, Ahituv N, Bisceglia L, et al. MYO6, the human homologue of the gene responsible for deafness in Snell's waltzer mice, is mutated in autosomal dominant nonsyndromic hearing loss. Am J Hum Genet 2001; 69: 635-40.

[13] Ahmed ZM, Morell RJ, Riazuddin S, et al. Mutations of MYO6 are associated with recessive deafness, DFNB37. Am J Hum Genet 2003; 72: 1315-22.

[14] Liu XZ, Walsh J, Mburu P, et al. Mutations in the myosin VIIA gene cause non-syndromic recessive deafness. Nat Genet 1997; 16: $188-90$.

[15] Weil D, Kussel P, Blanchard S, et al. The autosomal recessive isolated deafness, DFNB2, and the Usher 1B syndrome are allelic defects of the myosin-VIIA gene. Nat Genet 1997; 16: 191-3.

[16] Luijendijk MWJ, van Wijk E, Bischoff AMLC, et al. Identification and molecular modelling of a mutation in the motor head domain of myosin VIIA in a family with autosomal dominant hearing impairment (DFNA11). Hum Genet 2004; 115: 149-56.

[17] Lalwani AK, Goldstein JA, Kelley MJ, Luxford W, Castelein CM, Mhatre AN. Human nonsyndromic hereditary deafness DFNA17 is due to a mutation in nonmuscle myosin MYH9. Am J Hum Genet 2000; 67: 1121-8.

[18] Donaudy F, Snoeckx R, Pfister M, et al. Nonmuscle myosin heavychain gene MYH14 is expressed in cochlea and mutated in patients affected by autosomal dominant hearing impairment (DFNA4). Am J Hum Genet 2004; 74: 770-6

[19] Wang A, Liang Y, Fridell RA, et al. Association of unconventional myosin MYO15 mutations with human nonsyndromic deafness DFNB3. Science 1998; 280: 1447-51

[20] Naz S, Giguere CM, Kohrman DC, et al. Mutations in a novel gene, TMIE, are associated with hearing loss linked to the DFNB6 locus. Am J Hum Genet 2002; 71: 632-6.

[21] Kurima K, Peters LM, Yang Y, et al. Dominant and recessive deafness caused by mutations of a novel gene, TMC1, required for cochlear hair-cell function. Nat Genet 2002; 30: 277-84.

[22] Yasunaga S, Grati M, Cohen-Salmon M, et al. A mutation in OTOF, encoding otoferlin, a FER-1-like protein, causes DFNB9, a nonsyndromic form of deafness. Nat Genet 1999; 21:363-9.

[23] Varga R, Kelley PM, Keats BJ, et al. Non-syndromic recessive auditory neuropathy is the result of mutations in the otoferlin (OTOF) gene. J Med Genet 2003; 40: 45-50.

[24] Bork JM, Peters LM, Riazuddin S, et al. Usher syndrome 1D and nonsyndromic autosomal recessive deafness DFNB12 are caused by allelic mutations of the novel cadherin-like gene $\mathrm{CDH} 23$. Am J Hum Genet 2001; 68: 26-37.

[25] Verpy E, Masmoudi S, Zwaenepoel I, et al. Mutations in a new gene encoding a protein of the hair bundle cause non-syndromic deafness at the DFNB16 locus. Nat Genet 2001; 29: 345-9.

[26] Ahmed ZM, Smith TN, Riazuddin S, et al. Nonsyndromic recessive deafness DFNB18 and Usher syndrome type IC are allelic mutations of USHIC. Hum Genet 2002; 110: 527-31.
[27] Ouyang XM, Xia XJ, Verpy E, et al. Mutations in the alternatively spliced exons of USH1C cause non-syndromic recessive deafness. Hum Genet 2002; 111: 26-30.

[28] Ahmed ZM, Riazuddin S, Ahmad J, et al. PCDH15 is expressed in the neurosensory epithelium of the eye and ear and mutant alleles are responsible for both USH1F and DFNB23. Hum Mol Genet 2003; 12: 3215-23.

[29] Khan SY, Ahmed ZM, Shabbir MI, et al. Mutations of the RDX gene cause nonsyndromic hearing loss at the DFNB24 locus. Hum Mutat 2007; 28: 417-23

[30] Riazuddin S, Khan SN, Ahmed ZM, et al. Mutations in TRIOBP, which encodes a putative cytoskeletal-organizing protein, are associated with nonsyndromic recessive deafness. Am J Hum Genet 2006; 78: 137-42.

[31] Shahin H, Walsh T, Sobe T, et al. Mutations in a novel isoform of TRIOBP that encodes a filamentous-acting binding protein are responsible for DFNB28 recessive nonsyndromic hearing loss. Am J Hum Genet 2006; 78: 144-52.

[32] Mburu P, Mustapha M, Varela A, et al. Defects in whirlin, a PDZ domain molecule involved in stereocilia elongation, cause deafness in the whirler mouse and families with DFNB31. Nat Genet 2003; 34: 421-8.

[33] Ebermann I, Scholl HP, Charbel Issa P, et al. A novel gene for Usher syndrome type 2: mutations in the long isoform of whirlin are associated with retinitis pigmentosa and sensorineural hearing loss. Hum Genet 2007; 121: 203-11

[34] Naz S, Griffith AJ, Riazuddin S, et al. Mutations of ESPN cause autosomal recessive deafness and vestibular dysfunction. J Med Genet 2004; 41: 591-5.

[35] Liu XZ, Ouyang XM, Xia XJ, et al. Prestin, a cochlear motor protein, is defective in non-syndromic hearing loss. Hum Mol Genet 2003; 12:1155-62.

[36] Tlili A, Mannikko M, Charfedine I, et al. A novel autosomal recessive non-syndromic deafness locus, DFNB66, maps to chromosome $6 \mathrm{p} 21.2-22.3$ in a large Tunisian consanguineous family. Hum Hered 2005; 60: 123-8.

[37] Kalay E, Li Y, Uzumcu A, et al. Mutations in the lipoma HMGIC fusion partner-like 5 (LHFPL5) gene cause autosomal recessive nonsyndromic hearing loss. Hum Mutat 2006; 27: 633-9.

[38] Shabbir MI, Ahmed ZM, Khan SY, et al. Mutations of human TMHS cause recessively inherited nonsyndromic hearing loss. J Med Genet 2006; 43: 634-40.

[39] Lynch ED, Lee MK, Morrow JE, Welcsh PL, Leon PE, King M-C Nonsyndromic deafness DFNA1 associated with mutation of the human homolog of the Drosophila gene diaphanous. Science 1997; 278: $1315-8$.

[40] Beisel KW, Nelson NC, Delimont DC, Fritzsch B. Longitudinal gradients of KCNQ4 expression in spiral ganglion and cochlear hair cells correlate with progressive hearing loss in DFNA2. Brain Res Mol Brain Res 2000; 82: 137-49.

[41] Kubisch C, Schroeder BC, Friedrich T, et al. KCNQ4, a novel potassium channel expressed in sensory outer hair cells, is mutated in dominant deafness. Cell 1999; 96: 437-46.

[42] Mencia A, Gonzalez-Nieto D, Modamio-Hoybjor S, et al. A novel KCNQ4 pore-region mutation (p.G296S) causes deafness by impairing cell-surface channel expression. Hum Genet 2008; 123 : 41-53.

[43] Bespalova IN, Van Camp G, Bom SJH, et al. Mutations in the Wolfram syndrome 1 gene (WFS1) are a common cause of low frequency sensorineural hearing loss. Hum Mol Genet 2001; 10: 2501-8.

[44] Young TL, Ives E, Lynch E, et al. Non-syndromic progressive hearing loss DFNA38 is caused by heterozygous missense mutation in the Wolfram syndrome gene WFS1. Hum Mol Genet 2001; 10(26): 3111

[45] Komatsu K, Nakamura N, Ghadami M, et al. Confirmation of genetic homogeneity of nonsyndromic low-frequency sensorineural hearing loss by linkage analysis and a DFNA6/14 mutation in a Japanese family. J Hum Genet 2002; 47: 395-9.

[46] Vahava O, Morell R, Lynch ED, et al. Mutation in transcription factor POU4F3 associated with inherited progressive hearing loss in humans. Science 1998; 279: 1950-4.

[47] van Wijk E, Krieger E, Kemperman $\mathrm{MH}$, et al. A mutation in the gamma actin 1 (ACTG1) gene causes autosomal dominant hearing loss (DFNA20/26). J Med Genet 2003; 40: 879-84. 
[48] Zhu M, Yang T, Wei S, et al. Mutations in the gamma-actin gene (ACTG1) are associated with dominant progressive deafness (DFNA20/26). Am J Hum Genet 2003; 73: 1082-91.

[49] Peters LM, Anderson DW, Griffith AJ, et al. Mutation of a transcription factor, TFCP2L3, causes progressive autosomal dominant hearing loss, DFNA28. Hum Mol Genet 2002; 11: 287785 .

[50] Hand GM, Müller DJ, Nicholson BJ, Engel A, Sosinsky GE. Isolation and characterization of gap junctions from tissue culture cells. J Mol Biol 2002; 315(4): 587-600.

[51] Kelsell DP, Dunlop J, Stevens HP, et al. Connexin 26 mutations in hereditary non-syndromic sensorioneural deafness. Nature 1997; 387: 80-3

[52] Piatto VB, Moreira OA, Silva MA, Maniglia JV, Pereira MC, Sartorato EL. Correlation between audiometric data and the 35delG mutation in ten patients. Rev Bras Otorrinolaringol (Engl Ed) 2007; 73(6): 777-83.

[53] Janecke AR, Nekahm D, Loffler J, Hirst-Stadlmann A, Muller T, Utermann G. De novo mutation of the connexin 26 gene associated with dominant non-syndromic sensorineural hearing loss. Hum Genet 2001; 108: 269-70.

[54] Belintani Piatto V, Maria Goloni Bertollo E, Lúcia Sartorato E, Victor Maniglia J. Prevalence of the GJB2 mutations and the del(GJB6-D13S1830) mutation in Brazilian patients with deafness. Hear Res 2004; 196: 87-93.

[55] Xia JH, Liu CY, Tang BS, et al. Mutations in the gene encoding gap junction protein beta-3 associated with autosomal dominant hearing impairment. Nat Genet 1998; 20: 370-3.

[56] Van Laer L, Vrijens K, Thys S, et al. DFNA5: hearing impairment exon instead of hearing impairment gene? J Med Genet 2004; 41: 401-6.

[57] Azaiez H, Yang T, Prasad S, et al. Genotype-phenotype correlations for SLC26A4-related deafness. Hum Genet 2007; 122: $451-7$.

[58] Scott HS, Kudoh J, Wattenhofer M, et al. Insertion of beta-satellite repeats identifies a transmembrane protease causing both congenital and childhood onset autosomal recessive deafness. Nat Genet 2001; 27: 59-63.

[59] Zwaenepoel I, Mustapha M, Leibovici M, et al. Otoancorin, an inner ear protein restricted to the interface between the apical surface of sensory epithelia and their overlying acellular gels, is defective in autosomal recessive deafness DFNB22. Proc Nat Acad Sci 2002; 99: 6240-5.

[60] Wilcox ER, Burton QL, Naz S, et al. Mutations in the gene encoding tight junction claudin-14 cause autosomal recessive deafness DFNB29. Cell 2001; 104: 165-72.

[61] Ramzan K, Shaikh RS, Ahmad J, et al. A new locus for nonsyndromic deafness DFNB49 maps to chromosome 5q12.3q14.1. Hum Genet 2005; 116: 17-22.

[62] Riazuddin S, Ahmed ZM, Fanning AS, et al. Tricellulin is a tightjunction protein necessary for hearing. Am J Hum Genet 2006; 79: 1040-51.

[63] Delmaghani S, del Castillo FJ, Michel V, et al. Mutations in the gene encoding pejvakin, a newly identified protein of the afferent auditory pathway, cause DFNB59 auditory neuropathy. Nat Genet 2006; 38: 770-8.
[64] Usami S, Takahashi K, Yuge I, et al. Mutations in the COCH gene are a frequent cause of autosomal dominant progressive cochleovestibular dysfunction, but not of Meniere's disease. Eur J Hum Genet 2003; 11: 744-8.

[65] Wayne S, Robertson NG, DeClau F, et al. Mutations in the transcriptional activator EYA4 cause late-onset deafness at the DFNA10 locus. Hum Mol Genet 2001; 10: 195-200.

[66] Modamio-Hoybjor S, Mencia A, Goodyear R, et al. A mutation in CCDC50, a gene encoding an effector of epidermal growth factormediated cell signaling, causes progressive hearing loss. Am J Hum Genet 2007; 80: 1076-89.

[67] Abe S, Katagiri T, Saito-Hisaminato A, et al. Identification of CRYM as a candidate responsible for nonsyndromic deafness, through cDNA microarray analysis of human cochlear and vestibular tissues. Am J Hum Genet 2003; 72: 73-82.

[68] de Kok YJ, van der Maarel SM, Bitner-Glindzicz M, et al. Association between X-linked mixed deafness and mutations in the POU domain gene POU3F4. Science 1995; 267: 685-8.

[69] Legan PK, Richardson GP. Extracellular matrix and cell adhesion molecules in the developing inner ear. Semin Cell Dev Biol 1997; 8: 217-24.

[70] Brown MR, Tomek MS, Van Laer L, et al. A novel locus for autosomal dominant nonsyndromic hearing loss, DFNA13, maps to chromosome 6p. Am J Hum Genet 1997; 61: 924-7.

[71] McGuirt WT, Prasad SD, Griffith AJ, et al. Mutations in COL11A2 cause non-syndromic hearing loss (DFNA13). Nat Genet 1999; 23: 413-9.

[72] Chen W, Campbell CA, Green GE, et al. Linkage of otosclerosis to a third locus (OTSC3) on human chromosome 6p21.3-22.3. J Med Genet 2002; 39: 473-7.

[73] Verhoeven K, Van Laer L, Kirschhofer K, et al. Mutations in the human alpha-tectorin gene cause autosomal dominant nonsyndromic hearing impairment. Nat Genet 1998; 19: 60-2.

[74] Meyer NC, Alasti F, Nishimura CJ, et al. Identification of three novel TECTA mutations in Iranian families with autosomal recessive nonsyndromic hearing impairment at the DFNB21 locus. Am J Med Genet 2007; 143:1623-9.

[75] Fischel-Ghodsian N. Mitochondrial deafness. Ear Hear 2003; 24 303-13.

[76] Ballana E, Morales E, Rabionet R, et al. Mitochondrial 12S rRNA gene mutations affect RNA secondary structure and lead to variable penetrance in hearing impairment. Biochem Biophys Res Commun 2006; 341: 950-7.

[77] Hutchin TP, Parker MJ, Young ID, et al. A novel mutation in the mitochondrial tRNASer(UCN) gene in a family with nonsyndromic sensorineural hearing impairment. J Med Genet 2000; 37: 692-4.

[78] Han W, Han D, Jiang S. Mitochondrial DNA4977 deletions associated with human presbycusis. Zhonghua Er Bi Yan Za Zhi 2000; 35: 416-9.

[79] Piatto VB, Pereira MC, da Silva MA, Maniglia JV. Tracking of the genetic deafness associated to the aging in Brazilian patients Neurobiol Aging 2009; 30: 1173-4.

This is an open access article licensed under the terms of the Creative Commons Attribution Non-Commercial License (http://creativecommons.org/licenses/by$\mathrm{nc} / 3.0 /$ ), which permits unrestricted, non-commercial use, distribution and reproduction in any medium, provided the work is properly cited. 